\title{
Kekerasan dalam Rumah Tangga Perspektif Hak Asasi Manusia
}

\author{
Noor Fatimah Azzahra \\ Universitas Negeri Brawijaya. \\ E-Mail: azzahra@gmail.com
}

\begin{abstract}
This article is about the fact of domestic violence (KDRT) that peacock occurs in the community. Domestic violence (KDRT) can be positioned as a result of being born from a gender biased social system. In practice, domestic violence can occur in all layers of society from rich communities to the poor or from uneducated to educated groups. Domestic violence can be carried out by a person with full awareness that what he is doing is violence, but the perpetrator may perceive that the violent behavior is part of his right as a justification of the juridical authority or religious proposition. The focus of the study of this article is: First what factors cause violence against wives in the household? Second, How is domestic violence in the perspective of human rights?
\end{abstract}

Keywords: Domestic Violence, Human Rights, Gender Justice.

\begin{abstract}
Abstrak
Artikel ini tentang fakta kekerasan dalam rumah tangga (KDRT) yang merak terjadi di masyarakat. Kekerasan dalam rumah tangga (KDRT) dapat diposisikan sebagai akibat yang dilahirkan dari sebuah system social yang bias gender. Dalam prakteknya, KDRT bisa terjadi disemua lapisan masyarakat dari kelompok masyarakat kaya sampai masyarakat miskin atau dari kelompok tidak terdidik sampai yang terdidik sekalipun. KDRT bisa saja dilakukan oleh seorang dengan penuh kesadaran bahwa apa yang ia lakukan adalah kekerasan, namun bisa saja pelaku menganggap prilaku kekerasan yang dilakukan merupakan bagian dari hak yang ia miliki sebagai justifikasi dari
\end{abstract}


otoritas yuridis atau dalil agama. Fokus kajian artikel ini adalah: Pertama apa faktor penyebab timbulnya kekerasan terhadap isteri dalam rumah tangga? Kedua, Bagaimanakah kekerasan dalam rumah tangga dalam perspektif Hak Asasi Manusia (HAM)?

Kata Kunci: Kekerasan dalam Rumah Tangga, Hak Asasi Manusia, Keadilan Gender.

\section{A. Pendahuluan}

\section{Latar Belakang}

Islam sebagai agama pembebas dari ketertindasan dan penistaan kemanusiaan dengan visi "rahmatan lil 'alamin" membawa misi untuk mengikis habis praktek-praktek tersebut. Islam adalah agama yang mengayomi seluruh alam. Islam mengakui perbedaan sebagai kenyataan tak terbantahkan. Dengan pengakuan ini, Islam menghormati keragaman dan menganjurkan agar keragaman menjadi instrumen kerja sama di antara manusia. Perbedaan adalah sunnatullah, karena dengannya manusia bisa saling melengkapi (take and give). ${ }^{1}$

Dalam Islam, manusia baik laki-laki maupun perempuan adalah sama-sama sebagai makhluk Tuhan yang bermartabat (human dignity) dimana parameter kemuliaan seorang manusia tidak diukur dengan parameter biologis sebagai lakilaki maupun perempuan, akan tetapi kualitas dan nilai seseorang diukur dengan kualitas taqwanya kepada Allah Swt. Sebagaimana Firman Allah di dalam al-Qur'>an surat al-Hujurat [49]: 13 . $^{2}$

1 Syamsul Arifin Nababan, Hak Asasi Manusia (HAM) dalam Perpesktif Al-Qur'an dan Al-Sunna, http://www.ham.co.id, akses, 24.06.10.

2 Artinya "Hai manusia, Sesungguhnya Kami menciptakan kamu dari seorang laki-laki dan seorang perempuan dan menjadikan kamu berbangsa - bangsa dan bersuku-suku supaya kamu saling kenalmengenal. Sesungguhnya orang yang paling mulia diantara kamu disisi Allah ialah orang yang paling taqwa diantara kamu. Sesungguhnya Allah Maha mengetahui lagi Maha Mengenal." Ayat ini menegaskan bahwa semua manusia derajat kemanusiaanny sama di sisi Allah, tidak ada perbedaan antara satu suku dengan yang lain, juga tidak ada perbedaan 
Secara normativ-doktrinal diatas, Islam dengan tegas mengakui konsep kesejajaran antara laki-laki dan perempuan. ${ }^{3}$ Dari sini setidaknya ada dua hal yang bisa disimpulkan: Pertama, pengakuan secara umum atas kesetaraan anatar laki-laki dan perempuan, tanpa membedakan jenis kelamin. Kedua, mengakuan atas kesejajaran hak dan keawajiban antara laki-laki dan perempuan dalam berbagai bidang. ${ }^{4}$

Namun sangat ironis, kenyataan historis-empiris justru cenderung sebaliknya, yakni status dan peran perempuan diberbagai masyarakat hingga sekarang ini pada umumnya masih berada pada posisi dan kondisi yang belum mengembirakan. Impikasi yang ditimbulkan bermacmmacam, diantaranya perempuan mengalami ragam ketidakadilan, marginalisasi, subordinasi, stereotip, kekerasan dan beban kerja. ${ }^{5}$ Dengan kondisi rill seperti itu wajar apabila kemudian status peran perempuan dinilai lebih buruk dimanupun dibelahan bumi ini.

Kekerasan apapun yang terjadi dalam masyarakat, sesungguhnya berangkat dari suatu ediologi tertentu yang

antara nilai kemanusiaan laki-laki dan perempuan karena semua diciptakan dari seseorang laki0laki dan perempuan, yang jelas ayat diatas menegaskan bahwa kesatuan asal-usul manusia dengan menunjukan kesamaan derajat kemanusiaan, tidak wajar seseorang berbangga dan merasa diri lebih tinggi dari yang lain, bukan saja antar bangsa, suku, atau warna kulit, namu juga jenis kelamin, yang dinilai hanyalah ketaqwaannya, lihat, M. Quraish Shihab, Tafsir al-Misba>h "Pesan, Kesan dan Keserasian al-Qur'an, (Jakarta: Lentera Hati, 2001), hlm. 260261.

${ }^{3}$ Sejarah menuliskan bahwa Muhammad SAW (abad VII) dengan lahirnya Islam sebagai "rohmatan lil 'alamin" pun telah memperjuangkan hak-hak asasi manusia, seperti dalam Piagam Madinah, yang disinyalir sebagai hak asasi pertama kali yang terealisasi dalam konstitusi, Khutbah haji Wada', dll. Namun, perjuangan ini malah banyak disalahtafsirkan sebaliknya menjadi pendeskreditan terhadap wanita.Lihat Q.S. al-Taubah: 71-72, Q.S. al-Ahzab: 35, Q.S. al-Mu'min: 40 dll, lihat juga Haifaa A. Jawad, The Right of Women in Islam, (Britain: Macmillan Press, 1998), hlm. 11.

${ }^{4}$ Zaitunah Subhan, Tafsir Kebencian: Studi Kasusu Gender dalam Tafsir Qur'a>n, (Yogyakarta: LKiS, 1999), hlm. 4.

5 Penjelasan tentang jenis-jenis ketidak-adilan yang banyak dialami kaum perempuan ini; lihat, Mansour Faqih, Analsis Gender dan Transformasi Sosial, (Yogyakarta: Pustaka Pelajar, 1999), hlm. 12-23. 
mengesahkan penindasan di satu pihak, baik perorangan maupun kelompok, terhadap pihak lain yang disebabkan oleh anggapan ketidak setaraan yang ada dalam masyarakat. Pihak yang tertindas disudutkan pada posisi yang membuat mereka dalam ketakutan melalui cara penampakan secara periodic. $^{6}$ Pada umumnya masyarakat beranggapan bahwa lingkungan pubilk lebih berbahaya dibandingkan dengan di dalam rumah (domestic). Anggapan tersebut terbentuk karena kejahatan yang banyak diungkap dan dipublikasikan adalah kejahatan yang terjadi diluar lingkungan rumah. Sedangkan rumah dianggap sebagai tempat yang aman bagi anggota keluarga dan orang-orang yang tinggal didalamnya, tempat anggota keluarga dan orang-orang yang tinggal didalamnya dapat berinteraksi dengan landasan kasih, saling menghargai, dan menghormati.

Namun ternyata rumah dapat menjadi tempat yang paling mengerikan bagi anggota keluarga. ${ }^{7}$ Kekerasan dalam bentuk apapun dan derajat keseriusannya, ternyata dapat terjadi di dalam rumah, orang yang beranggapan rumah dapat menjadi tempat berlindung ternyata justru menjadi penyebab mala-

${ }^{6}$ Ridwan, "Kekerasan dalam Rumah Tangga : Perspektif Hukum Islam. Dalam. Jurnal Syir'ah, Vol. 14, No. 1, Hukum Islam dan Problematikan Kontemporer, (Yogyakarta: UIN Press, 2007), hlm. 162.

${ }^{7}$ Pada umumnya masyarakat beranggapan bahwa rumah menjadi panggung yang menyenangkan untuk sebuah pentas cinta kasih yang diperankan oleh setiap penghuninya. Rumah juga menjadi tempat sentral kembalinya setiap anggota keluarga setelah melalui pengembaraan panjang ditempat mengadu nasibnya masing-masing. Rumah yang mereka rasakan sebagai syurga, karena yang ada hanya cinta dan kebaikan. Setiap hari jatuh cinta. Anak selalu merindukan orang tua, demikian pula sebaliknya. Kebaikan telah menjadi pakaian sehari-hari keluarga, sehingga dapat terus melaju menempuh badai besar apapun. Betapa indahnya kehidupan ketika ia hanya berwajah kebaikan, namun ternyata rumah juga dapat menjadi tempat yang paling mengerikan bagi anggota keluarga. Rita Selena Kolibonso mengatakan bahwa: Kekerasan dalam rumah tangga sejauh ini tidak dikenal sebagai kejahatan dalam masyarakat, meskipun terjadi dibanyak tempat dalam bentuk seperti perkosaan, penyiksaan terhadap isteri, penyiksaan terhadap anak, incest, pemasungan, pembunuhan dan bentuk-bentuk kekerasan lainnya. Lihat. Rita Selena Kolibonso, Kejahatan itu Bernama Kekerasan Dalam Rumah Tangga, Jurnal Perempuan, No. 26, (Jakarta: yayasan Jurnal Perempuan, 2002), hlm. 8. 
petaka. Penaniayaan, perkosaan dan bahkan pembunuhan justru sering terjadi diantara anggota keluarga itu sendiri.

Kekerasan, ketidak-adilan serta ketidak-setaraan antara laki-laki dan perempuan yang kemudian melahirkan nilainilai patiarkhi. ${ }^{8}$ Semuanya tidak terlepas dari doktrin-doktrin yang ada, serta konstruk budaya patiarkhi yang mapan secara universal dan berlangsung selama berabad-abad, hal ini tidak lagi dipandang sebagai ketimpangan, bahkan ini diklaim sebagai "fakta ilmiah". ${ }^{9}$ Praktek-praktek kebiasaan dan tradisi yang berkembang selama ini cenderung mengekalkan mitos dominasi laki-laki atas perempuan. ${ }^{10}$ Keterbatasan dan kesempitan medan gerak perempuan kerapkali dijustifikasi oleh pemahaman literal ummat terhadap doktrin keagamaan, termasuk praktek-praktek dalam keluarga. ${ }^{11}$

Kekerasan dalam rumah tangga (KDRT) dapat diposisikan sebagai akibat yang dilahirkan dari sebuah system social yang bias gender. Dalam prakteknya, KDRT bisa terjadi disemua lapisan masyarakat dari kelompok masyarakat kaya sampai masyarakat miskin atau dari kelompok tidak terdidik sampai yang terdidik sekalipun.

${ }^{8}$ Sahbana, "Wanita Indonesia dalam Keluarga Persepektif Islam, dalam, Jurnal Ilmu Syari'ah, Keadilan Gender dalam Syari'at Islam, (Yogyakarta: UIN Press, 2001), hlm. 141.

${ }^{9}$ Sejarah kehidupan perempuan pra Islam juga merupaka tragedi kemanusiaan yang sangat mengerikan, bebagai variable penting ikut memberikan konstribusi lahirnya kekerasan dan penistaan terhadapa perempuan diantara lain system social, budata, politik dan ambisi politik penguasa ataupun mitos-motis sputar perempuan yang kemudian mendapat justifikasi teologis. Lihat, Bias Gender dalam Penafsiran alQur'a>n, Pidato Pengukuhan Guru Besar dalam Ilmu Tafsir, UIN Syarif Hidayatullah, Jakarta: 2002. Lihat juga, Siti Ruhaini Dzuhayatin, Teologi Feminis Islam "Suatu Refleksi Pergulatan Pemikiran Feminis dalam Wacana Islam di Indonesia, Jurnal Teologi Gema, edisi 55, hlm. 109.

${ }^{10}$ Pandangan yang membenarkan domonasi pria atas wanita sangat subur dikonstruksi oleh panafsiran ajaran agama yang mysoginis, argumen-argumen tafsir atas ayat sosiologis yang bersifat kontekstual dipatenkan menjadi ayat-ayat teologis yang bersifat absolut. Lihat, Abd. Salam Arief, "Reinterpretasi Nas dan Bias Gender dalam Hukum Islam".ı, dalam, Jurnal Ilmu Syari'ah, Keadilan Gender dalam Syari'at Islam, (Yogyakarta: UIN Press, 2001), hlm. 36.

${ }^{11}$ Abd. Salam Arief, "Reinterpretasi Nas dan Bias Gender dalam Hukum Islam" hlm. 35. 
KDRT bisa saja dilakukan oleh seorang dengan penuh kesadaran bahwa apa yang ia lakukan adalah kekerasan, namun bisa saja pelaku menganggap prilaku kekerasan yang dilakukan merupakan bagian dari hak yang ia miliki sebagai justifikasi dari otoritas yuridis atau dalil agama. ${ }^{12}$ Menurut Mansour Fakih, ketidak adilan gender antara laki-laki dan perempuan tersebut menefestasikan dalam bentuk ketidakadilan, antara lain: marginalisasi, subordinasi, dan pembentukan strereotip atau pembelaan negative, kekerasan, beban kerja lebih banyak serta sosialisasi ideology nilai peran gender. ${ }^{13}$

Terjadinya kekerasan dalam rumah tangga bermula dari adanya pola relasi kekuasaan yang timpang antara laki-laki (suami) dengan perempuan (isteri). Kondisi ini tidak jarang mengakibatkan tindak kekerasan oleh suami terhadap isterinya, kepercayaan menyatakan bahwa kekerasan ini dilakukan sebagai kekuasaan kepala keluarga. Justifikasi atas otoritas itu bisa lahir didukung oleh perangkat Undangundang negara atau oleh persepsi-persepsi social dalam bentuk mitos-mitos superioritas seorang laki-laki yang dipercayai oleh masyarakat tertentu. Dengan menggunakan alur pikir semacam ini, maka kekerasan yang terjadi dalam lingkup rumah tangga (domestic violence) merupaka jenis kekerasan yang berbasis gender. Artinya, kekerasan itu lahir disebabkan oleh perbedaan peran-peran gender yang dikonstruksi secara social di mana salah satu piham menjadi subordinat dari pihak lain. ${ }^{14}$

Oleh karena itu, melihat fakta-fakta diatas, sudah menjadi kewajiban pemerintah untuk melindungi masyarakat hak-hak perempuan umumnya, dan hak-hak perempuan dalam perlindungan hukum di dalam rumah tangga khususnya. Hak kebebasan serta hak-hak lainnya dalam ranah rumah tangga merupakan hak asasi manusia (HAM) yang harus dilindungi (hak perempuan), yang tentunya ini di

12 Ridwan, "Kekerasan dalam Rumah Tangga, dalam. Jurnal Syir'ah, hlm. 162.

13 Mansour Fakih, Analisis Gender dan Transformasi Sosial, (Yogyakarta: Pustaka Pelajar, 1996), 12.

14 Ridwan, "Kekerasan dalam Rumah Tangga, dalam. Jurnal Syir'ah, hlm. 165-166. 
perlukan supremasi hukum untuk melindungi hak-hak perempuan tersebut, kebijakan hukum itu dperlukan demi kepastian hukum bagi korban kekerasan dalam rumah-tangga (KDRT) atas kekerasan yang lakukan oleh suami. Dalam hak ini, pemerintah wajib melindungi, jika tidak maka, pemerintah telah dikatan sebagai pelanggar HAM.

\section{Rumusan Masalah}

a. Apa faktor penyebab timbulnya kekerasan terhadap isteri dalam rumah tangga?

b. Bagaimanakah kekerasan dalam rumah tangga dalam perspektif Hak Asasi Manusia (HAM)?

\section{B. Fakta Kekerasan dalam Rumah Tangga}

Konsep KDRT mungkin belum dikenal oleh masyarakat secara luas, di dalam Undang-undang PKDRT kekerasan dalam rumah tangga (KDRT) adalah setiap perbuatan terhadap seseorang terutama wanita, yang berakibat timbulnya kesengsaraan atau penderitaan secara fisik, seksual, psikologis, dan/penelantaran rumah tangga termasuk ancaman untuk melakukan perbuatan, pemaksaan atau perampasan kemerdekaan (hak) secara melawan hukum dalam lingkup rumah tangga tersebut. ${ }^{15}$

Kekerasan terjadi ketika seseorang bertindak dengan cara-cara yang tidak patut dan menggunakan kekuatan fisik yang melanggar hukum dan melukai diri sendiri, orang lain atau lingkungannya. Menurut Mansur Faqih sebagaimana dikutip oleh Eti Nurhayati berpendapat bahwa kekerasan (violence) adalah serangan atau (assault) terhadap fisik atau integritas mental spikologis seseorang. Kekerasan lahir karena adanya ototritas kekuasaan dimana kelompok masyarakat yang dalam posisi subordinat akan selalu menjadi korban kekerasan. ${ }^{16}$

${ }^{15}$ Lihat, Pasal 1 UU. No. 23 Tahun 2004 tentang Penghapusan Kekerasan Dalam Rumah Tangga.

16 Eti Nurhayati, "Domestik Violence", Jurnal, EQUALITA STAIN Cirebon, Vol. 3 No. 3 Juni, 2003, hlm. 48-49. 
Kekerasan dalam rumah tangga (domestic violence) adalah bentuk penganiayaan (abose) oleh suami terhadap isterinya baik secara fisik (patah tulang, memar, kulit tersayat) maupun emosional/psikologis (rasa cemas, deresi dan perasaan rendah diri). Dalam rumusan lain kekerasan dalam rumah tangga didefinisikan sebagai setiap perbuatan yang dilakukan oleh seseorang secara sendiri atau bersamasama terhadap seorang perempuan atau terhadap seorang perempuan atau terhadap pihak yang tersubordinasi lainya dalam lingkup rumah tangga. Dalam perkembangannya, kekerasan dalam rumah tangga sesungguhnya tidak hanya terjadi antara suami dan isteri saja.

Kekerasan bukan hanya terjadi pada perempuan (isteri) namun kekerasan sering dialami oleh anak, kasus-kasus kekerasan terhadap anak biasanya berkaitan sangat erat dengan pandangan dan pemahaman mengenai anak dan hakhak anaknya serta ketidak berdayaan dan ketergantungan anak pada orang tua atau anggota keluarga yang lebih dewasa. Karena belum dewasa, anak dianggap belum bisa menentukan arah hidupnya sehingga segala sesuatau harus ditentukan oleh orang tuanya, meskipun hal tersbut harus bertentangan dengan kehendak anak. Anak juga sering dianggap sebagai hak milik, sehingga apapun yang akan ditentukan atau dilakukan oleh orang tuanya terhadap anak tersebut adalah hak orang tua. ${ }^{17}$

Ada keyakinan bahwa, kasus-kasus kekerasan dalam rumah tangga yang terungkap dan diberitakan hanyalah sangat sedikit dibandingkan dengan kejadian senyatanya, sehingga sering diistilahkan sebagai puncak gunung es yang tampak dilautan. ${ }^{18}$ Laporan yang datang dari berbagai penjuru dunia mencatat bahwa kekerasan dalam rumah tangga terjadi di segala lapisan masyarakat.pelaku dan korban berasal dari berbagai suku bangsa, ras, agama, kelas social, dan tingkat pendidikan yang manapun. Oleh karena itu, dimilikinya UU. No. 23 tahun 2004 tentang Penghapusan

${ }^{17}$ G. Widiartana, Kekerasan Dalam Rumah Tangga "Perspektif Perbandingan HUKUM", (Yogyakarta: Universitas Atma Jaya Yogyakarta, 2009), hlm.5.

${ }^{18}$ Rita Selena kolibonso, Kejahatan itu Bernama Rumah Tangga, hlm. 7 . 
Kekerasan Dalam Rumah Tangga dapat diharapkan sebagai babak permulaan yang baik bagi upaya mengakhiri kekerasan dalam rumah tangga. ${ }^{19}$

Menurut LBH APIK tujuan dari UU. No. 23 tahun 2004 tentang Penghapusan Kekerasan Dalam Rumah Tangga adalah untung menghilangkan atau meminimalisir tindak pidana KDRT. Dari fakta yang terjadi dilapangan, pihak yang sering menjadi korban KDRT adalah para kaum perempuan dan anak-anak. Jumlah korban KDRT mengalami peningkatan dari hari kehari. Namun ironisnya penegakan hukum untuk mencapai keadilan bagi si korban juga menunjukan angka yang berbanding terbalik dengan jumlah angka korban tersebut. Selain itu UU KDRT juga bertujuan untuk menjaga keutuhan rumah tangga, dimana keutuhan rumah tangga dapat terjadi jika setiap anggota keluarga, menyadari hak dan kewajibannya masing-masing tidak ada satu anggota yang dapat melakukan kesewenang-wenangan. Keutuhan yang dimaksudkan disini adalah posisi yang sama antara sesama anggota keluarga, posisi yang seimbang antara suami isteri dan anak serta orang tua dan tidak ada satu pihak yang merasa disubordinatkan dengan pihak yang lain. ${ }^{20}$

Sebagaimana pengertian KDRT yang telah di paparkan diatas, bahwa kekerasan yang mengakibatkan timbulnya kesengseraan dan penderitaan, yang dilindungi oleh UU PKDRT adalah orang yang berada dalam rumah tangga, baik suami/isteri, anak (anak kandung/tiri/sesusuan), saudara, atau orang-orang yang bekerja/menetap dalam rumah tangga tersebut, termasuk pembantu rumah taangga (PRT) dan sopir. $^{21}$

\section{Sebab-Sebab Kekerasan Terhadap Isteri dalam Rumah Tangga}

Di dalam rumah tangga, ketegangan maupun konflik merupakan hal yang biasa. Perselisishan pendapat, perdebatan, pertengkaran, saling mengejek atau bahkan

${ }^{19}$ Sulistyowati Irianto, Perempuan dan Hukum, hlm. 312.

${ }^{20}$ www. Pemantauanperadilan. com.

21 Hamim Ilyas dan Rachmad Hidayat, Membina Keluarga Barokah, (Yogyakarta: PSW UIN Sunan Kalijaga, 2006), hlm. 50-51. 
memaki merupakan suatu hal yang umum terjadi. Tapi semua itu, pada era globlalisasi dapat menjadi bagian dari bentuk kekerasan dalam rumah tangga yang secar spesifik mengacu kepada pengertian kekerasan terhadap perempuan yang ada dalam Deklarasi Penghapusan Kekerasan Terhadap Perempuan. $^{22}$

Di negara-negara yang mempunyai undang-undang khusus kekerasan dalam rumah tangga (Law ofs Domestic Violence), kejahatan ini dapat dibawa ke Pengadilan dan mereka yang menjadi korban difasilitasi dalam hukum khusus. Kekerasan dalam rumah tangga bisa menimpa siapa saja, termasuk ibu, bapak, isteri, anak atau pembantu rumah tangga. ${ }^{23}$ Akan tetapi kebanyakan korban kekerasan dalam rumah tangga adalah pihak perempuan (isteri). ${ }^{24}$ Seperti yang dilaporkan oleh Gelles dan Cornell bahwa hampir semua kasus kekerasan domestic dialami oleh perempuan (isteri), ini semua terbukti oleh luka-luka yang diderita para isteri. Bila ada satu dua kausus laki-laki teraniaya itu biasanya disebabkan oleh pembelaan diri dari pihak perempuan (isteri). ${ }^{25}$

Secara sederhana faktor-faktor yang menimbulkan kekerasan terhadap isteri dapat dirumuskan menjadi dua factor: pertama, faktor eksternal dan kedua, faktor internal.

\section{Faktor Eksternal}

Penyebab eksternal timbulnya tindak kekerasan terhadap perempuan berkaitan dengan hubungan kekuasaan suamiisteri dan diskriminasi Gender di kalangan masyarakat. Kekuasan merupakan kata sarapan dari kata potere bermakna "saya dapat", yang secara esensi berarti menguasai. Saya

${ }^{22}$ Fathul Djannah dkk., Kekerasan Terhadap Isteri, (Yogyakarta: LKiS, 2003), hlm. 16.

${ }^{23}$ Kalibonso, R.S., "kekerasan Terhadap Perempuan dalam Rumah Tangga sebagai Pelanggar Hak Asasi Manusia." Dalam, A.S. Luhalima (Ed.) Pemahaman Terhadap Bentuk-Bentuk Kekerasan terhadap Perempuan dan Alternatif Pemecahannya, (Jakarta: Pusat Kajian dan Fewler al "Convention Watch", 2000), hlm. 109.

${ }^{24}$ Faraha Ciciek, Ikhtiar Mengatasi Kekerasan dalam Rumah Tangga, (Jakarta: LKAJ, PSP, The Asia Foundation, 1999), hlm. 22.

${ }_{25}$ Gelles, R.J., Intimate Violence in Families, (Kalifornia: Sage Poblikations, 1990), hlm. 32. 
dapat melakukan sesuatu untuk mendapatkan kekuasaan. Saya dapat menghasilkan efek pada sesuatu atau seseorang. ${ }^{26}$

Kekuasan dalam perkawinan diekspresikan dalam dua area. Kelompok pertama, dalam hal pengambilan keputusan dan control atau pengaruh. Kelompok kedua, yang ada dibelakang layar, seperti ketegangan konflik dan penganiayaan. Sementara itu, Safilios Rothschild mengatakan, struktur kekuasaan keluarga berada dalam tiga komponen: individu yang memiliki otoritas, yaitu orang yang diberikan hak legitimasi untuk memutuskan menurut budaya dan norma social, kemudian indifidu membuat keputusan dan individu yang mampu menunjukan pengaruh dan kekuasaan, dalam kebanyakan masyarakat, suami adalah orang yang memiliki kekuasaan yang menjadi kepala keluarga. Artinya, suamilah yang mempunyai otoritas, membuat keputusan, dan memiliki pengaruh terhadap isteri dan anggota keluarga lainnya. $^{27}$

Lebih lanjut dapat dikatakan bahwa kekuasaan suami dalam perkawinan terjadi karena unsur-unsur cultural di mana terdapat norma-norma di dalam kebudayaan tertentu yang memberikan pengaruh yang menguntungkan suami. Pembedaan peran dan posisi antara suami-isteri di dalam keluarga dan masyarakat diturunkan secara cultural dalam masyarakat pada setiap generasi bahkan sampai diyakini sebagai ideologi. Idiologi gender ini kemudian diyakini sebagai ketentuan Tuhan atau Agama yang tidak dapat diubah. Idiologi ini selanjutnya mendefinisikan dan menggariskan bagaimana perempuan dan laki-laki seharusnya berfikir dan bertindak. Hak istimewa yang dimiliki oleh kaum laki-laki sebagai akibat konstruksi social ini, menempatkan suami sebagai seseorang yang mempunyai kekuasaan yang lebih tinggi dari perempuan, kenyataan ini akhirnya melahirkan "diskriminasi gender" atau ketidakadilan gender. ${ }^{28}$

26 Scanzoni, L., Men, Women and Changes: A Siciologi of Marriage end Family, (New YorkMc Graw Hill Book, 1979), hlm. 304.

27 Safillos Rothschilld, The Study of Family Power Structure, Jurnal of Merriage and Familly, 1970, hlm. 32.

${ }^{28}$ Fathul Djannah dkk., Kekerasan Terhadap Isteri, hlm. 18. 
Ketidak-adilan gender ini seperti diungkap oleh Mansour Fakih, termanifistasi dalam berbagai bentuk, yakni marginalisasi atau proses pemiskinan ekonomi, kekerasan (veolence), Strereotyping, subordinasi atau anggapan perempuan kurang penting dalam keputusan politik, dan kekerasan ekonomi dalam bentuk bekerja lebih panjang dan lebih banyak tetapi tidak dinilai.

Kekuasaan suami yang tinggi terhadap isteri juga dipengaruhi oleh penguasaan suami dalam sistem keuangan. Karena suami menghabiskan waktu disektor yang menghasilkan uang sementara isteri mengurusi rumah tangga dan mngasuh anak, membuat masyarakat memandang pekerjaan suami lebih bernilai. "suatu masyarakat di mana uang lebih menentukan nilai, perempuan adalah kelompok yang dianggap bekerja di luar ekonomi. Margaret Baton menambahkan bahwa pekerjaan rumah tangga tidak dianggap penting karena tidak mempunyai nilai uang. ${ }^{29}$ Oleh karena itu, menurut Gilar Gillespie, untuk meraih kekuasaan seseorang isteri harus mempunyai sumber keuangan. Ia harus berpartisipasi di dalam ekonomi dan tingkat pendidikannya harus setara dengan suaminya atau bahkan harus lebih. ${ }^{30}$

Tetapi analisis ini tidak sepenuhnya benar, sebab dalam kenyataan masih banyak ditemukan kekerasan yang menimpa isteri yang bekerja. Factor cultural bahwa laki-laki mendimonasi terutama dalam masyarakat yang menganut system patriarkhi masih berlaku luas.

Study-study tentang perempuan yang bekerja diberbagai tempat di Indonesia, bahkan dibelahan dunia lainnya menunjukkan bahwa pembagian kerja menurut seks tetap bertahan dalam kemapanan dalam budaya. Sebagian besar laki-laki belum siap untuk tidak selalu melayani. Di pihak lain perempuan (isteri) memiliki perasaan bersalah jika lakilaki (suami) terabaikan dengan alasan dia bekerja mencari nafkah. Kemudian timbul pertanyaan, bukankah budaya tidak mengharuskan untuk mencari nafkah?

29 Margaret Baston, “The Politikal Economy of Women's Liberation. Dalam, Monthly Review, 1989, hlm. 3-4.

${ }^{30}$ Gilar Gillespie, "Who has the Power, The Marital Struggle" Journal of Merriage and The Family, 1971, hlm. 32. 
Keterlibatan perempuan dalam ekonomi yang tidak didukung dengan perubahan dalam sistem dan kondisi social budaya menimbulkan persoalan baru bagi perempuan. Sebagian ibu rumah tangga ia diharuskan oleh nilai budaya yang berlaku untuk bertanggung jawab penuh terhadap keluarga. Hal ini menyebabkan terabaikannya peran perempuan dalam ekonomi karena dianggap sebagai kegiatan sampingan atau tambahan. ${ }^{31}$

\section{Faktor Internal}

Faktor internal timbulnya kekerasan terhadap perempuan dalah kondisi psikis dan kepribadian suami sebagai pelaku tindak kekerasan R. Langley, Ricard. D. dan Levy. C. menyatakan bahwa kekerasan laki-laki terhadap perempuan (isteri) dikarenakan: ${ }^{32}$

a. Sakit mental

b. Pecandu alkokhol dan obat

c. Penerimaan masyarakat terhadap kekerasan

d. Kurangnya komunikasi

e. Penyelewengan seks

f. Citra diri yang rendah

g. Frustasi

h. Perubahan situasi dan kondisi

i. Kekerasan sebagai sumber daya untuk menyelesaikan masalah (pola kebiasaan turunan dari keluarga atau orang tua).

Dari dua factor diatas, dapat disimpulkan bahwa secara keseluruhan terdapat sedikitnya enam factor yang menyebabkan terjadinya kekerasan suami terhadap isteri:

1).Fakta bahwa laki-laki dan perempuan tidak diposisikan setara dalam masyarakat.

2).Masyarakat masih membesarkan anak laki-laki dengan didikan yang bertumpukan pada kekuatan fisik. Yaitu untuk menumbukan keyakinan bahwa mereka harus kuat dan berani serta tidak toleran.

${ }^{31}$ Fathul Djannah dkk., Kekerasan Terhadap Isteri, hlm. 20.

${ }^{32}$ R. Langley, Ricard. D. dan Levy. C, Memukul Isteri, Trj.R. Mosasi, (Jakarta: Cakrawala, tt.), hlm. 31. 
3).Budaya yang mengkondisikan perempuan atau isteri tergantung kepada laki-laki atau kepada suami, khususnya secara ekonomi.

4). Persepsi tentang kekerasan yang terjadi dalam rumah tangga yang dianggap harus ditutup karena termasuk wilayah prifat suami-isteri dan bukan sebagai persoalan social.

5).Pemahaman yang keliru terhadap ajaran agama tentang penghormatan pada posisi suami, tentang aturan mendidik isteri. Dan tentang ajaran kepatuhan isteri terhadap suami.

6).Kondisi kepribadian dan psikologis suami yang tidak stabil dan tidak benar.

Selanjutnya, tidak terungkapnya kasus-kasus yang sebenarnya terjadi tersebut tidak lepas dari sikap korban dan atau keluarga korban sendiri, diantaranya adalah:

a. Korban menganggap bahwa peristiwa yang menimpanya tersebut merupakan hal yang biasa dan sudah seharusnya demikian. Korban tidak mengetahui bahwa peristiwa yang menimpanya itu sudah termasuk dalam katagori perbuatan yang dapat dipidana.

b. Korban menganggap bahwa keutuhan rumah tangga lebih penting dari pada harus memperkarakan peristiwa yang dialaminya, yang berpotensi merusak hubungannya dengan pelaku.

c. Korban atau keluarga korban merasa mali jika tindak pidana yang dialaminya diketahui oleh orang lain. Hal ini biasanya terjadi untuk tindak pidana yang menyangkut kesusilaan atau tindak pidana lainnya yang dianggap dapat merendahkan harga diri korban atau keluarganya.

d. Korban merasa bahwa kerugian yang dialami tidak berarti baginya dibandingkan dengan kerepotan dan kerugian/penderitaan lebih besar yang harus ia tanggung ketika tindak pidana itu dilaporkan atau diadukan ke aparat hukum. 
e. Korban merasa takut untuk melaporkan atau mengadukan tindak pidana tersebut karena ada ancaman pada pelaku atau orang yang bersimpati pada pelaku.

f. Korban yang merupakan satu-satunya saksi dari tindak pidana tersebut meninggal dunia.

Disamping karena sikap dan kondisi korban sendiri, tidak dilaporkan atau di adukannya kasus-kasus kekerasan dalam rumah tangga juga disebabkan oleh adanya anggapan bahwa yang terjadi dalam lingkungan rumah tangga merupakan urusan intern rumah tangga.

\section{Kekerasan dalam Rumah Tangga Perspektif Hak Asasi Manusia}

Membicarakan tentang hak asasi manusia (HAM) berarti membicarakan dimensi kehidupan manusia. HAM ada bukan karena diberikan oleh masyarakat dan kebaikan dari negara, melainkan berdasarkan martabatnya sebagai manusia. ${ }^{33}$ Hak asasi manusia (HAM) adalah hak-hak yang dimiliki manusia semata-mata karena ia manusia. Umat manusia memilikinya bukan karena diberikan kepadanya oleh masyarakat atau berdasarkan hukum positif, melainkan semata-mata berdasarkan martabatnya sebagai manusia.

Dalam arti ini, maka meskipun setiap orang terlahir dengan warna kulit, jenis kelamin, bahasa, budaya dan kewarganegaraan yang berbeda-beda, ia tetap mempunyai hak-hak tersebut. Inilah sifat universal dari hak-hak tersebut. Selain bersifat universal, hak-hak itu juga tidak dapat dicabut (inalienable). ${ }^{34}$ Pengakuan atas eksistensi manusia menandakan bahwa manusia sebagai makhluk hidup adalah

${ }^{33}$ Franz Magnis Suseno, Etika Politik: Prinsip-Prinsip Moral Dasar Kenegaraan Modern (Jakarta: PT Gramedia Pustaka Utama, 2001), hlm. 121.

${ }^{34}$ Suparman Marzuki, Eko Riyadi (Penyunting/Editor), Hukum Hak Asasi Manusia (Yogyakarta: Pusat Studi Hak Asasi Manusia Universitas Islam Indonesia PUSHAM UII, 2008), hlm. 7. 
ciptaan Tuhan Yang Maha Kuasa, yang patut memperoleh aprisisasi secara positif. ${ }^{35}$

Segala bentuk kekerasan dan penyiksaan baik lahir maupun batin, terutama Kekerasan Dalam Rumah Tangga (KDRT) merupakan pelanggaran terhadap hak asasi manusia (HAM), dan kajahatan terhadap martabat kemanusiaan serta bentuk diskriminasi yang wajib dihapus. Hal ini sebagaimana dijelaskan di dalam UU. No. 39 tahun 1999 tentang Hak Asasi Manusia. Dalam UU HAM tersebut dijelaskan bahwa: Setiap orang berhak untuk bebas dari penyiksaan, penghukuman atau perlakuan yang kejam, tidak manusiawi, merendahkan derajat dan martabat kemanusiaannya. Pasal 33 [1].

Di dalam konstitusi negara Indonesia (UUD 1945) dengan tegas menyatakan bahwa segala warga Negara adalah pemilik kedudukan yang sama di dalam hukum, oleh karena itu, segala bentuk diskriminasi terhadap perempuan wajib dihapuskan karena tidak sesuai dengan Pancasila dan UUD 1945. Dari latar belakang di atas, maka upaya perlindungan terhadap hak-hak perempuan merupakan sebuah keniscayaan. Untuk itu, segala bentuk diskriminasi harus dihapuskan. Asumsi, persepsi, dan cara pandang terhadap perempuan yang patriarkhis harus diubah. Karena negara Indonesia adalah negara hukum, prinsip negara hukum adalah adanya perlindungan dan penghormatan terhadap hak asasi manusia (HAM) warga negara.

Dalam praktek penegakan hukum di Indonesia, telah lahir berbagai instrument yuridis sebagai kebijakan pemerintah untuk menciptakan tatanan masyarakat yang menghormati hak asasi manusia (HAM) dan igaliter, khususnya aturan-aturan hukum yang digunakan dalam peanggulangan kekerasan dalam rumah tangga, perlakuan diskriminati. Adapun upaya perlindungan dari tindak pidana

35 Majda El-Muhtaj, Hak Asasi Manusia dalam Konstitusi Indonesia: Dari UUD 1945 Sampai dengan Amandemen UUD 1945 Tahun 2002 (Jakarta: KENCANA, 2009), hlm.56. 
kekerasan yang berbasis gender dalam lingkup keluarga (rumah tangga) baik kekerasan fisik, psikhis maupun seksual telah diatur dalam Undang-undang Nomor 23 Tahun 2004 tentang Penghapusan Kekerasan Dalam Rumah Tangga. ${ }^{36}$

Selain itu, tindak kekerasan terhadap perempuan sebagai isu global dapat dengan nyata dilihat dari ditetapkannya sejumlah instrument hukum Internasional sehubungan dengan fenomena ini, antara lain adalah:

a. Vienna Declaration and Programme of Acton (1993)

b. Cinvention on The Elimination of all Form of Diskrimination Against Women (1979)

c. Declaration on The Elimination of Violence Against Women (1993)

d. Beijing Declaration and Platform for Action (1995)

Walaupun Indonesia telah merespon dan meratifikasi isu global ini tantang Penghapusan Segala Bentuk diskriminasi terhadap Perempuan (Konvention on the Elimination of all forms of Diskrimination against Women) melalui Undangundang No. 7 than 1984. Namun selama ini terjadi dalam peta pemerintahan dan perpolitikan di tanah air, telah terjadi peminggiran-peminggiran hak-hak perempuan akibat ketidak-adilan gender. Stigma bahwa bahwa perempuan berada dalam posisi domestic.

Konvensi tentang Hak-hak Asasi kaum Perempuan tersebut diatas, khususnya Konvensi tentang Peghapusan diskriminasi Perempuan mengisyaratkan perlunya suatu tindakan khusus sementara untuk mewujudkan kesetaraan dan keadilan gender. ${ }^{37}$ Lahirnya Undang-undang Nomor 23 Tahun 2004 tentang Penghapusan Kekerasan Dalam Rumah Tangga merupakan refleksi dari adanya untutan social yang

36 Ridwan, "Kekerasan dalam Rumah Tangga. Dalam. Jurnal Syir'ah, hlm. 163

37 Ani W. Soetjibto, Hak-hak Politik Wanita : Refleksi dan Peluang di Era Reformasi"dalam T.O. Ihrami, Penghapusan Diskriminasi Terhadap Wanita, (Bandung: Alumni, 2000), hlm. 296. 
mengharuskan Undang-undang ini lahir dan sekaligus sebagai pengakuan bahwa praktek-praktek kekerasan dalam rumah tangga itu merupakan sebagai penghormatan terhadap hak asasi manusia (HAM). Ketakutan, ketidak-adilan dan perlakuan diskriminatif yang dialami oleh perempuan (isteri) dalam rumah tangga atas perlakuan penyiksaan oleh suami merupakan hak asasi perempuan yang harus dilindungi secara hukum.

\section{E. Kesimpulan}

Dari urauan diatas, maka dapat disimpulkan beberapa hal sebagai berikut: Pertama, kekerasan dalam rumah tangga merupakan bagian dari kekerasan yang berbasis gender, karena kekerasan itu lahir sebagai akibat adanya ketimpangan pola relasi kekuasaan antara laki-laki dan perempuan yang kemudian mendapat justifikasi baik oleh hukum negara maupun keyakinan-keyakinan agama sebagai hasil dari interpretasi teks keagamaan yang bias gender. Kedua, kekerasan di dalam rumah tangga baik kekerasan fisik, psikis, ekonomi maupun penelantaran rumah tangga baik secara yuridis formal (UU PKDRT) maupun secar hukum Islam jelas merupakan bentuk pelanggaran terhadap hak asasi manusia (HAM) dalam bentuk diskriminasi, pelabelan negative, marginalisasi dan kekerasan.

Ketiga, membangun pola relasi yang egaliter serta adil dan jauh dari praktek kekerasan (violence) dalam konteks kehidupan keluarga merupakan bagian dari tugas kamanusiaan sekaligus keagamaan. Salah satu upayanya adalah mengembangkan pola interpretasi teks keagamaan yang berperspektif keadilan gender dan melakukan proses penyadaran kepada masyarakat tentang pentingnya relasi yang berkeadilan gender. Sedangkan berkaitan dengan upaya penegakan supermasi hukum perlu pengawasan oleh masyarakat terhadap aparat penegak hukum (structure of the 
law) untuk secara konsekuen mengawal pemberlakuan UU PKDRT.

\section{Daftar Pustaka}

Abd. Salam Arief, "Reinterpretasi Nas dan Bias Gender dalam Hukum Islam”.।, dalam, Jurnal Ilmu Syari'ah, Keadilan Gender dalam Syari'at Islam, Yogyakarta: UIN Press, 2001

Abd. Salam Arief, "Reinterpretasi Nas dan Bias Gender dalam Hukum Islam".।, dalam, Jurnal Ilmu Syari'ah, Keadilan Gender dalam Syari'at Islam, Yogyakarta: UIN Press, 2001.

Ani W. Soetjibto, Hak-hak Politik Wanita : Refleksi dan Peluang di Era Reformasi"dalam T.O. Ihrami, Penghapusan Diskriminasi Terhadap Wanita, Bandung: Alumni, 2000.

Ani W. Soetjibto, Hak-hak Politik Wanita : Refleksi dan Peluang di Era Reformasi", Dalam T.O. Ihrami, Penghapusan Diskriminasi Terhadap Wanita, Bandung: Alumni, 2000.

Barda Nawawi Arief, Perbandingan Hukum Pidana, Jakarta: CV Rajawali, 1999.

Departemen Agama Republik Indonesia, Al-Qur'a>n dan Terjemahannya, CV Toha Putra, 1996

Eti Nurhayati, "Domestik Violence", Jurnal, EQUALITA STAIN Cirebon, Vol. 3 No. 3 Juni, 2003

Faraha Ciciek, Ikhtiar Mengatasi Kekerasan dalam Rumah Tangga, Jakarta: LKAJ, PSP, The Asia Foundation, 1999.

Fathul Djannah dkk., Kekerasan Terhadap Isteri, Yogyakarta: LKiS, 2003 
Franz Magnis Suseno, Etika Politik: Prinsip-Prinsip Moral

Dasar Kenegaraan Modern, Jakarta: PT Gramedia Pustaka Utama, 2001.

G. Widiartana, Kekerasan Dalam Rumah Tangga "Perspektif Perbandingan HUKUM", Yogyakarta: Universitas Atma Jaya Yogyakarta, 2009.

Gelles, R.J., Intimate Violence in Families, Kalifornia: Sage Poblikations, 1990.

Gilar Gillespie, "Who has the Power, The Marital Struggle" Journal of Merriage and The Family, 1971.

Haifaa A. Jawad, The Right of Women in Islam, Britain: Macmillan Press, 1998

Hamim Ilyas dan Rachmad Hidayat, Membina Keluarga Barokah, Yogyakarta: PSW UIN Sunan Kalijaga, 2006.

Kalibonso, R.S., "kekerasan Terhadap Perempuan dalam Rumah Tangga sebagai Pelanggar Hak Asasi Manusia." Dalam, A.S. Luhalima (Ed.) Pemahaman Terhadap Bentuk-Bentuk Kekerasan terhadap Perempuan dan Alternatif Pemecahannya, Jakarta: Pusat Kajian dan Fewler al "Convention Watch", 2000.

Kekerasan Dalam Rumah Tangga Meningkat. Laporan wartawan KOMPAS Mahdi Muhammad, Sabtu, 28 Maret 2009

Lawrence Friedman, The Legal System: A Social Science Perspektive, New York: Russel Sage Poundation, 1975.

Lisa Tuttle, Encyclopiedia of Feminisme, New York: Facts on File Pubilkation, 1986.

M. Quraish Shihab, Tafsir al-Misba $>$ h "Pesan, Kesan dan Keserasian al-Qur'an, Jakarta: Lentera Hati, 2001 
Majda El-Muhtaj, Hak Asasi Manusia dalam Konstitusi Indonesia: Dari UUD 1945 Sampai dengan Amandemen UUD 1945 Tahun 2002 Jakarta: KENCANA, 2009.

Mansour Fakih, Analisis Gender dan Transformasi Sosial, Yogyakarta: Pustaka Pelajar, 1996

Mansour Faqih, Analsis Gender dan Transformasi Sosial, Yogyakarta: Pustaka Pelajar, 1999

Margaret Baston, “The Politikal Economy of Women's Liberation. Dalam, Monthly Review, 1989.

Mufidah Ch, Paradigma Gender, Malang: Bayu Media Publishing, 2004

Ninuk Widyantoro, Kesehatan Repruduksi, Jakarta: Yayasan Kesehatan Perempuan, 2005.

R. Langley, Ricard. D. dan Levy. C, Memukul Isteri, Trj.R. Mosasi, Jakarta: Cakrawala, tt.

Ridwan, "Kekerasan dalam Rumah Tangga : Perspektif Hukum Islam. Dalam. Jurnal Syir'ah, Vol. 14, No. 1, Hukum Islam dan Problematikan Kontemporer, Yogyakarta: UIN Press, 2007

Rita Selena Kolibonso, Kejahatan itu Bernama Kekerasan Dalam Rumah Tangga, Jurnal Perempuan, No. 26, Jakarta: Yayasan Jurnal Perempuan, 2002

Safillos Rothschilld, The Study of Family Power Structure, Jurnal of Merriage and Familly, 1970.

Sahbana, "Wanita Indonesia dalam Keluarga Persepektif Islam, dalam, Jurnal Ilmu Syari'ah, Keadilan Gender dalam Syari'at Islam, Yogyakarta: UIN Press, 2001

Scanzoni, L., Men, Women and Changes: A Siciologi of Marriage end Family, New YorkMc Graw Hill Book, 1979 
Siti Ruhaini Dzuhayatin, Teologi Feminis Islam "Suatu Refleksi Pergulatan Pemikiran Feminis dalam Wacana Islam di Indonesia, Jurnal Teologi Gema, edisi 55

Sulistyowati Irianto, Perempuan dan Hukum "Menuju Hukum yang Berperspektif Kesetaraan dan Keadilan, Jakarta: Yayasan Obor Indoensia, 2008

Suparman Marzuki, Eko Riyadi (Penyunting/Editor), Hukum Hak Asasi Manusia, Yogyakarta: Pusat Studi Hak Asasi Manusia Universitas Islam Indonesia PUSHAM UII, 2008.

Syamsul Arifin Nababan, Hak Asasi Manusia (HAM) dalam Perpesktif Al-Qur'an dan Al-Sunna, http://www.ham.co.id, akses, 24.06.10.

Undang-undang R.I. No. 23 tahun 2004 tentang Penghapusan Kekerasan Dalam Rumah Tangga

Zaitunah Subhan, Tafsir Kebencian: Studi Kasusu Gender dalam Tafsir Qur'a>n, Yogyakarta: LKiS, 1999 